\title{
格子状地盤改良の格子間隔に対する地震時の沈下解析 SIMULATIONS OF SETTLEMENT ABOUT THE GRID SPAN OF GRID-FORM DEEP MIXING WALLS UNDER EARTHQUAKE
}

\author{
金田一広*, 津國正一**, 本多 剛*, 内田明彦* \\ Kazuhiro KANEDA, Shoichi TSUKUNI, Tsuyoshi HONDA \\ and Akihiko UCHIDA
}

\begin{abstract}
For liquefaction countermeasure based on grid-form deep mixing walls, the grid interval has conventionally been designed using the excess pore water pressure ratio or the FL value, and conditions under which liquefaction does not occur in the ground within the grid. However, in the case of seismic motions with a long duration, such as that which occurred during the 2011 earthquake off the Pacific coast of Tohoku, used as a design seismic motion, the increase in the excess pore water pressure in the ground within the grid becomes greater than that for a seismic motion with a shorter duration and an equivalent acceleration level. Centrifuge model vibration testing and numerical simulations were conducted to obtain the knowledge required for a performance design focused on settlement occurring in the ground within the grid. The sands with different relative densities are usually in a structured, overconsolidated and anisotropic state. The Super/subloading Yield Surface Cam-clay model with rotational hardening (SYS Cam-clay model) is powerful for incorporating these features. We found that the numerical simulations reproduced the experimental data well. It is indicated that there is the possibility of settlement evaluations under earthquake.
\end{abstract}

Keywords : Liquefaction, Grid-form deep mixing walls, Numerical simulation 液状化, 格子状地盤改良, 数值解析

\section{1. はじめに}

2011年に発生した東北地方太平洋沖地震では，津波による甚大な 人的被害と共に, 浦安市や潮来市をはじめとする東京湾岸地域およ び利根川流域で，液状化による宅地の被害が発生した1)。戸建住宅 では, 地震の摇れによる被害ではなく, 地盤の液状化によって沈下 し全壊ないし半壊になる被害が発生した。これは, 東北地方太平洋 沖地震の継続時間が長いことが原因の一つと考えられている。

さて, 格子状に深層混合処理工法で地盤改良する耐液状化対策工 法は, 兵庫県南部地震と東北地方太平洋沖地震に対して, 建物基礎 の液状化対策として採用された事例で夜状化防止効果が実証されて いる2),3)。従来までに格子状地盤改良は古賀4)らによる $1 \mathrm{G}$ 場の実験や, 高橋(5)，入江ら ${ }^{6)}$ による遠心模型実験による研究がなされている。い ずれも地盤中の間隙水圧比に着目している。このような状況を踏ま えて現在の格子状地盤改良の設計では, 過剩間隙水圧比かFL值に着 目し，液状化が発生しない格子間隔を用いてきている。しかし，継 続時間が長い地震や極大地震などに対して液状化しない過剩間隙水 圧比を設定するには，格子間隔が狭くなることが予想され経済的で
はない。また，今後はレベル 2 地震など極大地震に対して 2 次設計 がなされることが予想される。間隙水圧比による手法に加えて地盤 の沈下量に着目した評価手法の検討の必要性が出てきている。しか し，格子内地盤で発生する沈下量に着目した既往の研究がほとんど ないのが現状である。そこで本研究では，格子内地盤の地表面沈下 量に着目した遠心模型実験とそれを数值解析によって再現すること を試みた。

遠心模型実験では異なる格子間隔が混在する格子状改良地盤モデ ルを作製し相対密度を変えた 2 種類の実験を行い地表面沈下，加速 度および地盤の間隙水圧を測定した。一方，数值解析は 2 相系動的 有限要素法を実施した。地震時の砂地盤の沈下は弾性成分よりダイ レイタンシーによる塑性圧縮が卓越する。そのため地盤の構成式に は塑性変形によって塑性圧縮が表現できるSYSカムクレイモデルを 導入した 7 。

以下に本論文の構成を述べる。第 2 章では模型実験の概要と地盤 の構成式の簡単な説明および解析モデルを示す。第3章では実験結 果と解析結果の比較を示し, 第4章でまとめを述心゙る。

\footnotetext{
* (株竹中工務店技術研究所 主任研究員·工博

*** (侏竹中土木技術・生産本部 部長 $\cdot$ 工修
}

Chief Researcher, Takenaka Research \& Development Institute, Dr. Eng.

Senior Manager, Technology \& Production Development Division, Takenaka Civil Engineering \& Construction Co., Ltd., M. Eng. 


\section{2. 遠心模型実験および数值解析の概要}

（1）遠心模型実験の概要 8,9$)$

図1に60G場で行った遠心模型振動実験の模型地盤の平面図と断 面図を示す。せん断土槽 (幅 $800 \mathrm{~mm} \times$ 奥行き $530 \mathrm{~mm} \times$ 高さ $230 \mathrm{~mm}$ ) 内に設計基準強度 $\mathrm{fc}=1.5\left(\mathrm{~N} / \mathrm{mm}^{2}\right)$ の改良体剛性（GA）に相当する改 良壁厚 $\mathrm{t}=0.9 \mathrm{~m}$ (以降，実大スケール換算で表示)のエポキシ製の格子 状改良地盤模型を, 砂碩層に $1 \mathrm{~m}$ 根入れして設置した。格子状改良地 盤の天端は, 地下水位と同じ地表面から $1 \mathrm{~m}$ 下 $(\mathrm{GL}-1 \mathrm{~m})$ とした。格子 状改良地盤の格子間隔(改良壁の中心間隔で表示する)は， $4 \mathrm{~m} \times 5.25 \mathrm{~m}(\mathrm{Da}), 8 \mathrm{~m} \times 5.25 \mathrm{~m}(\mathrm{Db}), 8 \mathrm{~m} \times 10.5 \mathrm{~m}(\mathrm{Dc}), 12 \mathrm{~m} \times 10.5 \mathrm{~m}(\mathrm{Dd})$ の 4 種類とした。地盤は砂碟で作成した厚さ $2 \mathrm{~m}$ の支持層の上に，相 対密度 $\mathrm{Dr}=50,80 \%$ の豊浦砂で厚さ $12 \mathrm{~m}$ の砂層を作成した。地盤の 作製方法について述べる。 Dr= $50 \%$ は高さ $40 \mathrm{~cm}$ で $3 \mathrm{~mm}$ のスリット, $\mathrm{Dr}=80 \%$ は高さ $62 \mathrm{~cm}$ で $2.5 \mathrm{~mm}$ スリットを装着した巻出し装置によ り空中落下によって地盤を作成している。模型スケールで1cmの層 厚で密度の管理を実施している。地下水位はGL-1mとしたので, 液 状化層の厚さは $11 \mathrm{~m}$ となる。模型地盤の飽和に用いた間隙流体は, 相似則で実大スケールの透水係数よりも少し小さな透水係数にする ために, シリコンオイル $(50 \mathrm{CS})$ を用いて地盤を飽和させた。異なる 格子間隔の各格子内中央地盤と, 格子状改良地盤外の周辺地盤で, 過剩間隙水圧 - 水平応答加速度と地表面沈下量の計測を, 図1に示 す各計測点で行なった。入力地震動には, 東北地方太平洋沖地震時 にK-NET浦安で観測された地震波のEW成分(図2(a))を用いて，200 秒間加振した。この地震波の最大加速度は $157 \mathrm{gal}$ で，地表面にある 観測地点は地震時に液状化が発生していない。また, 振動台で観測 された加速度時刻歴を図 $2(\mathrm{~b})$ に示す。若干最大加速度が小さくなっ ている。

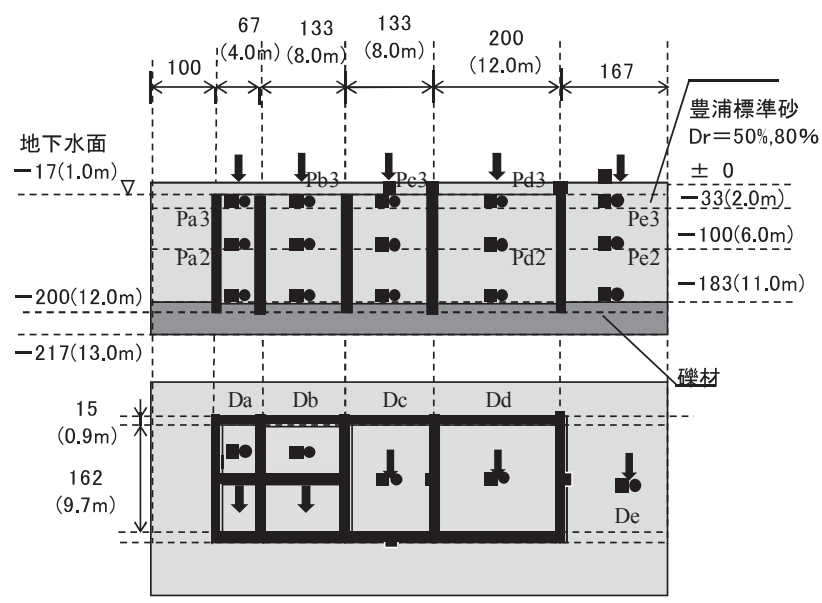

- 間隙水圧計 - 加速度計 \変位計 図 1 遠心模型地盤の平面図と断面図 (単位 $\mathrm{mm} ，$ 括弧内は実スケール換算値)

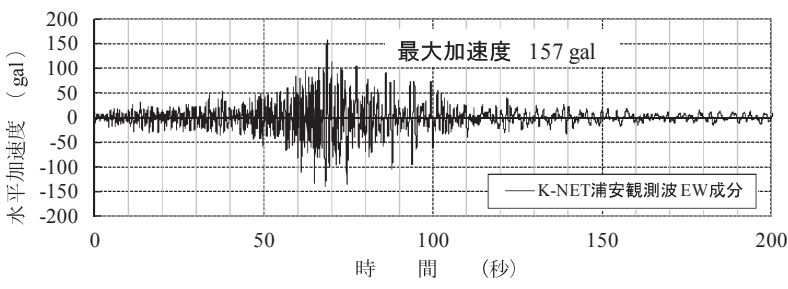

（a） 入力に用いたK-NET浦安観測波(EW成分）

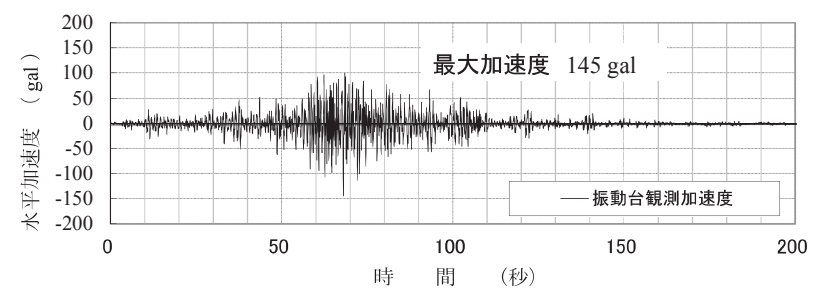

（b）振動台で観測された加速度

図2 入力加速度の比較

（2）地盤の構成式

地盤の構成式は名古屋大学地盤力学研究室が開発した土骨格構造 の働きを記述できるSYS カムクレイモデル7)を用いた。詳細は参考 文献 7)に譲るが，ここでは塑性ポテンシャルと発展側のみ示す。異 方性を考慮した骨格構造のない正規降伏面，骨格構造を考慮した上 負荷面，および過圧密を考慮した下負荷面により構成される。図 3 及び次式に塑性ポテンシャルを示す。

$\mathrm{MD} \ln \frac{\widetilde{p}^{\prime}}{\widetilde{p}_{0}^{\prime}}+\mathrm{MD} \ln \frac{\mathrm{M}^{2}+\eta^{* 2}}{\mathrm{M}^{2}}+\mathrm{MD} \ln R^{*}-\mathrm{MD} \ln R+\varepsilon_{v}^{p}=0$

ここで， $\widetilde{p}^{\prime} ， \tilde{p}_{0}^{\prime}$ は 正規降伏面の平均有効応力，初期の平均有効応

力, $\mathrm{M}$ は限界状態定数, $\eta^{*}=\sqrt{3 / 2 \hat{\boldsymbol{\eta}} \cdot \hat{\boldsymbol{\eta}}}, \hat{\boldsymbol{\eta}}=\boldsymbol{\eta}-\boldsymbol{\beta}, \boldsymbol{\eta}=\mathbf{S} / p^{\prime}$ で, $\mathbf{S}$

は偏差応カテンソル, $\boldsymbol{\beta}$ は回転硬化テンソル, $\mathrm{D}=(\tilde{\lambda}-\widetilde{\kappa}) /\left(1+\mathrm{e}_{0}\right) / \mathrm{M}$ は

ダイレイタンシー定数 $\left(\tilde{\lambda}\right.$ : 圧縮指数, $\widetilde{\kappa}$ : 膨潤指数, $\mathrm{e}_{0}$ : 初期間 隙比）を示す。また， $R^{*}$ は構造の程度を示し正規降伏面と上負荷 面の比 $\left(0 \leq R^{*} \leq 1\right)$ で定義され 0 に近いと高位な構造，1 亿近いと練 返しや骨格構造のない低位な構造を示す。例えば，砂の場合ゆるい 砂では高位な構造, 密な砂は低位な構造として表現寸る。 $R$ は過圧 密比の逆数で, 上負荷面と下負荷面の比 $(0 \leq R \leq 1)$ で定義され 0 に 近いと過圧密比が大きい状態, 1 に近いと正規圧密状態を示す。 $\varepsilon_{v}^{p}$ は 塑性体積ひずみ(圧縮を正)を示す。塑性変形とともに下記に示す発 展則によって上負荷面は正規降伏面に漸近し低位な構造へ，下負荷 面は上負荷面に漸近し正規圧密状態へ推移寸る。

$\dot{R}^{*}=U^{*}\left\|\dot{\boldsymbol{\varepsilon}}^{p}\right\|, \quad \dot{R}=U\left\|\dot{\boldsymbol{\varepsilon}}^{p}\right\|$

$\dot{\boldsymbol{\beta}}=\frac{b_{r}}{\mathrm{D}} \sqrt{\frac{2}{3}}\left\|\dot{\boldsymbol{\varepsilon}}_{s}^{p}\right\|\|\hat{\boldsymbol{\eta}}\|\left(m_{b} \frac{\hat{\boldsymbol{\eta}}}{\|\hat{\boldsymbol{\eta}}\|}-\boldsymbol{\beta}\right)$

ここで $U^{*}, U$ は非負の関数, $\boldsymbol{\beta}, \dot{\boldsymbol{\varepsilon}}^{p}, \dot{\boldsymbol{\varepsilon}}_{s}^{p}, b_{r}, m_{b}$ は回転硬化変数,

塑性ひずみ速度, 塑性せん断ひずみ速度, 回転硬化指数, 回転硬化 限界定数である。関連流れ則を仮定し, Prager の適応条件を満足す るように弾塑性構成式を構築する。 


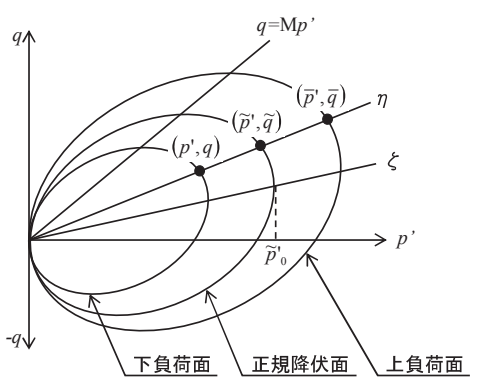

図 3 3つの塑性ポテンシャル(SYS カムクレイモデル)

\section{（3）塑性圧縮のメカニズム}

一般にカムクレイモデルのような $e \sim \log p p^{\prime}$ 関係から導かれる構成 式ではダイレイタンシー $\mathrm{D}=(\tilde{\lambda}-\tilde{\kappa}) /\left(1+\mathrm{e}_{0}\right) / \mathrm{M}$ に基づく土の圧縮が 基本となる。しかし, 砂質地盤では液状化時に間隙比で 0.1 以上の圧 縮が発生し, 砂質土の $\tilde{\lambda}, \widetilde{\kappa}$ は粘性土に比べて小さく, ダイレイタン シーだけではこのような大きな圧縮を表現することができない。そ こで, 本研究では土骨格構造, すなわち土のかさばりを考慮した構 成式を用いている。高位な構造 $\left(R^{\star}\right.$ が $0 に$ 近い)は低位な構造 $\left(R^{\star} か ゙ 1\right.$ に近い)に比心間隙比が大きいが耐力も大きくなる特徵がある。また， 式(1)の物質時間微分をとり整理すると下記のようになる。

$\dot{\varepsilon}_{v}{ }^{p}=\dot{f}+\frac{\tilde{\lambda}-\widetilde{\kappa}}{1+e_{0}}\left(\frac{\dot{R}^{*}}{R^{*}}-\frac{\dot{R}}{R}\right), f=\mathrm{MD} \ln \frac{\widetilde{p}^{\prime}}{\widetilde{p}_{0}^{\prime}}+\mathrm{MD} \ln \frac{\mathrm{M}^{2}+\eta^{* 2}}{\mathrm{M}^{2}}$

この式から塑性変形が進展し構造の劣化 $\left(\dot{R}^{*}>0\right)$ が進むと体積圧 縮が発生することが分かる。その圧縮量は初期の構造の程度による。 一方, 過圧密の解消 $(\dot{R}>0)$ が進むと体積膨張が発生する。砂質土の 場合は構造劣化のスピードが過圧密の解消より勝るので塑性圧縮が 卓越する。これらの詳細なメカニズムは参考文献に譲る10)。

\section{（4）解析メッシュ}

図 4 に解析メッシュを示す。実スケールで実験と同様に格子間隔 を設定している。液状化層は $11 \mathrm{~m}$ とし, 液状化層上部に $1 \mathrm{~m}$ の非液 状化層を設けた。実験ではゴムメンブレンを介してせん断土槽で加 振しており, 解析では砂地盤の外側に土とせん断土槽の $\mathrm{z}$ 方向がフ リー $(\mathrm{x}, \mathrm{y}$ 方向は土と固定 $)$ なゴムメンブレンに相当する厚さ $10 \mathrm{~cm}$ の層を設け，動的解析では鋼の質量 $\left(7.8 \mathrm{~g} / \mathrm{cm}^{3}\right)$ をせん断土槽を模擬 するように節点に与えた。地盤の地下水位は GL-1m とした。表 1 に設定した材料定数を示寸。弾塑性パラメータは過去の論文たとえば 8)を参考に典型的なものを本論文では採用した。初期の構造の程度 と間隙比に関しては，実験の沈下量を説明できるような值を設定し た。相対密度の違いは構造の程度および初期の間隙比で変化させ, その他の弾塑性パラメータや発展則パラメータは同じものである。 基盤層と非液状化層は間隙比が小さい密な地盤とし, 改良体は 2 相 系弾性体とした。図 5 にこの構成モデルを用いて相対密度 50\%(以 下 Dr50 などと表記する)の拘束圧 $100 \mathrm{kPa}$ における動的変形試験 のシミュレーション結果を示す。 $G_{0}$ は下記の式より計算される。

$G=\frac{3(1-2 v)}{2(1+v)} K, K=\frac{1+e}{\kappa} p^{\prime}$

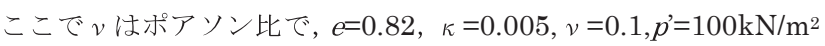
とし $G_{0}=39,709 \mathrm{kN} / \mathrm{m}^{2}$ である。解析で用いた入力地震動は振動台で 観測されたものを入力した。図 6 に実験で入力した加速度と実験時
に振動台で計測した水平方向加速度の加速度応答スペクトルの比較 を示す。なお，図 2 に示すように地震動は 150 秒を超えるとほとん ど加速度応答が見られないため解析では加速度は 150 秒まで与え, その後加速度入力をせずに 300 秒まで圧密解析を実行した。解析で は入力加速度 0.01 秒間隔で行い, 計算時間ステップは 0.001 秒とし, 線形補完した。また, 有限要素の刻み幅は $1 \mathrm{~m}$ 間隔とし, 初期の Vs は $150 \mathrm{~m} / \mathrm{s}$ 程度であり有効周波数帯は $12 \mathrm{~Hz}$ 程度としている。

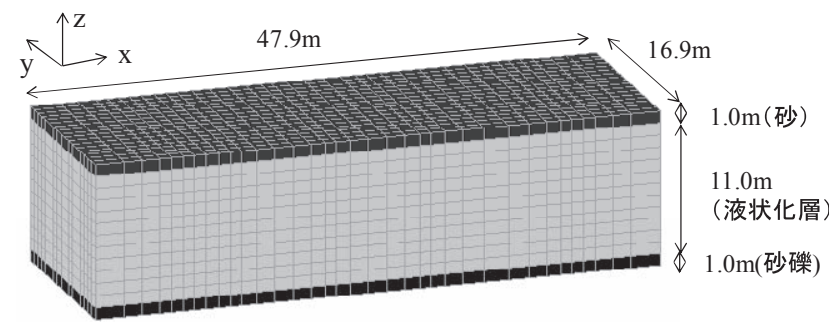

全体図

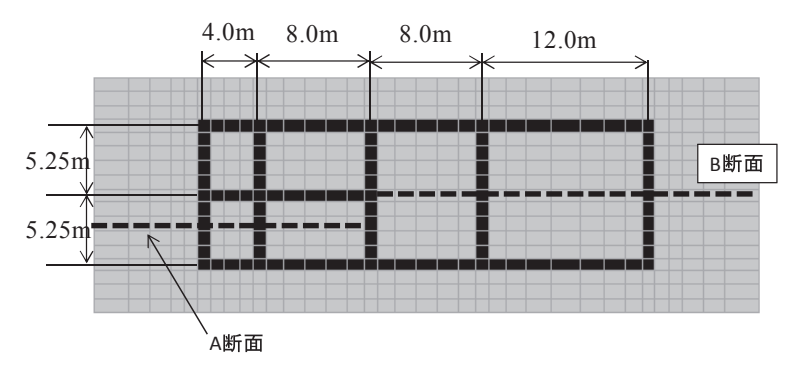

格子付近の詳細

図 4 解析メッシュ

表 1 材料定数

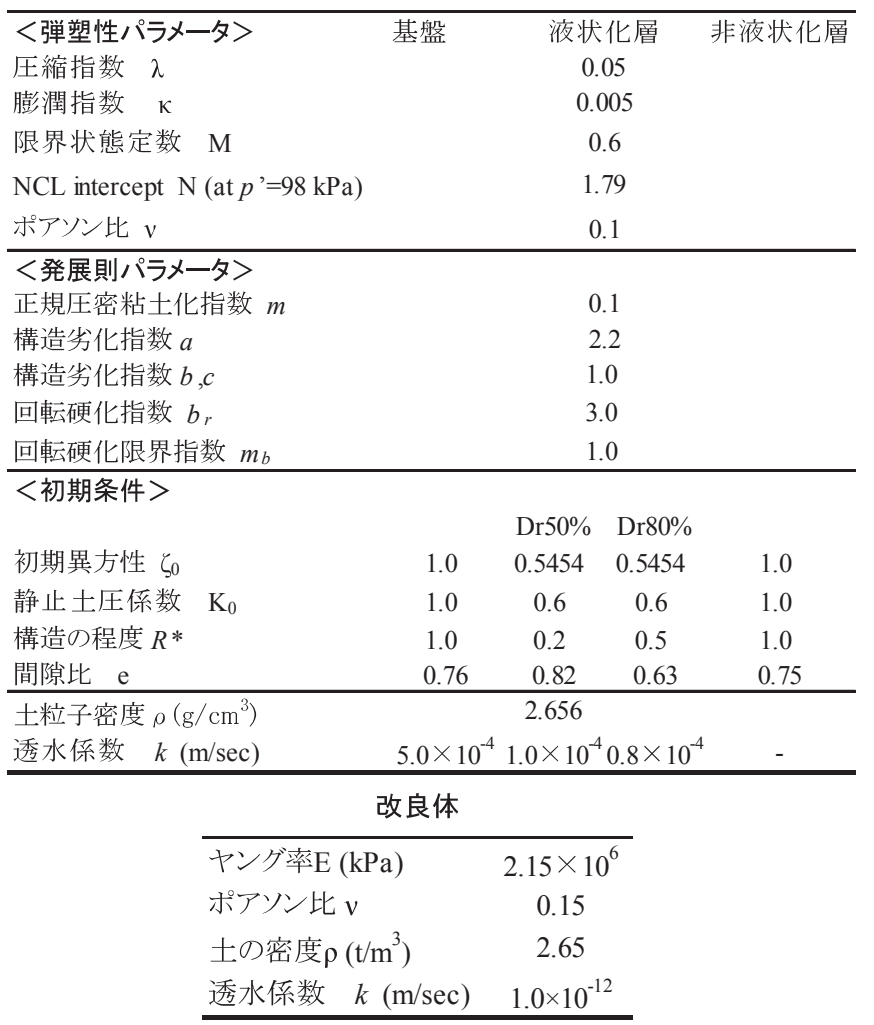




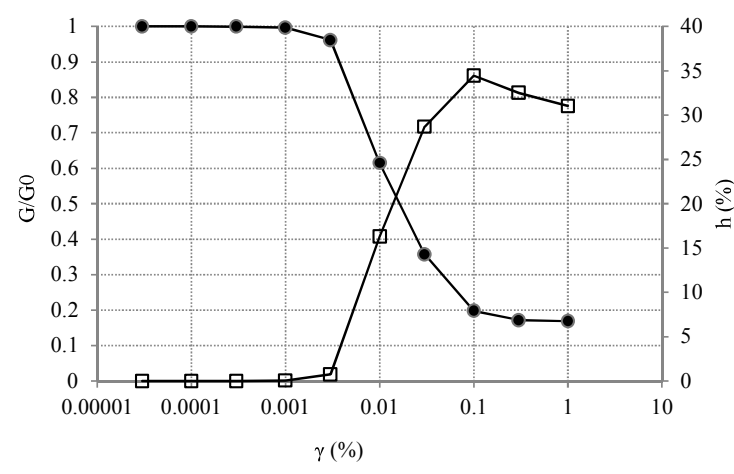

図 5 動的変形試験のシミュレーション結果

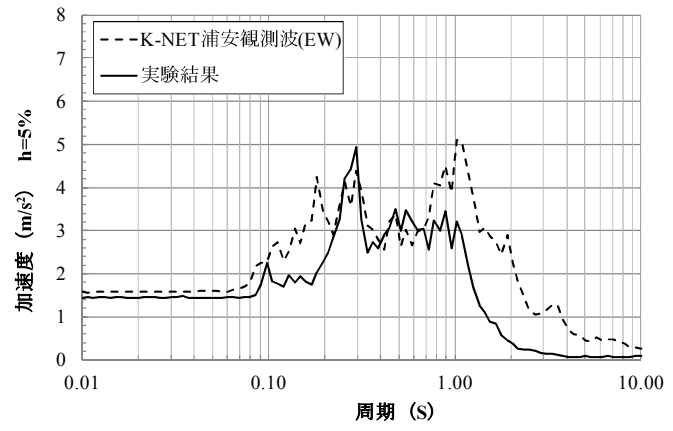

図 6 加速度応答スペクトルの比較
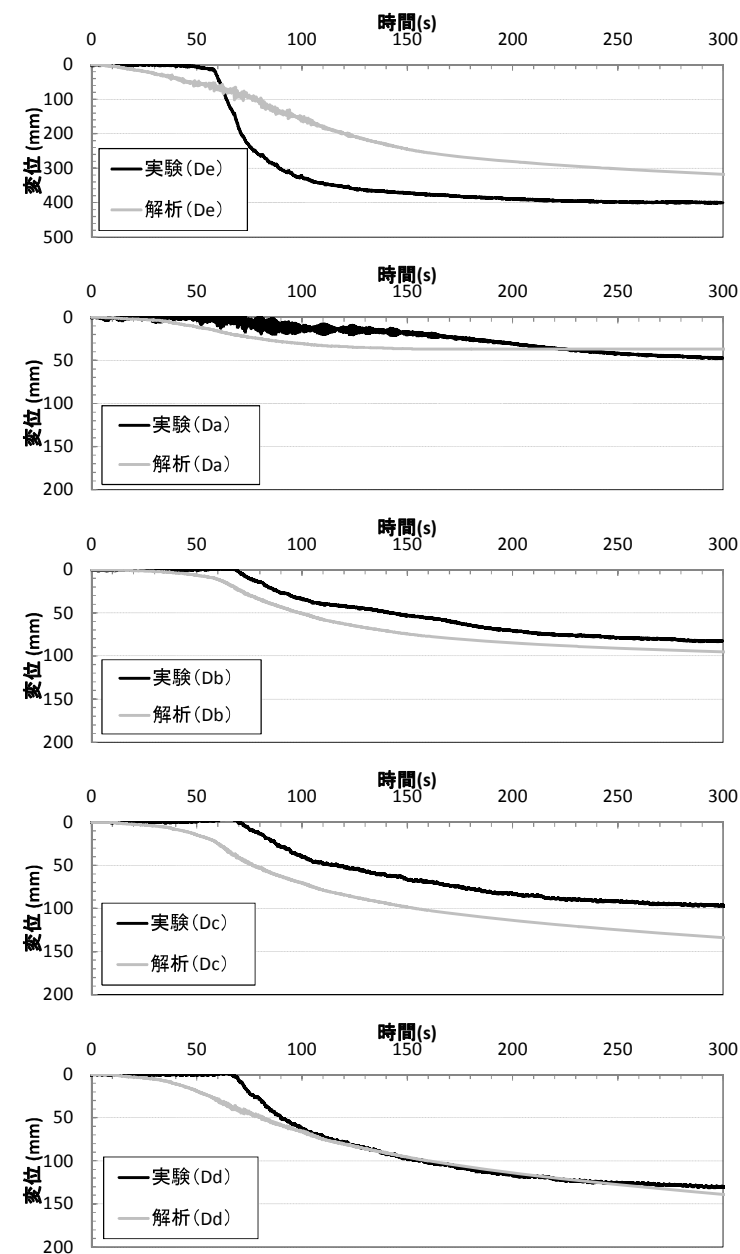

Dr50

\section{3. 実験結果と解析結果の比較}

(1) 沈下量の比較

図 7 に上から周辺地盤 De(図 1 を参照), 格子が狭いものから順に （Da,Db,Dc,Dd）地表面沈下量の実験結果と解析結果を示す。Dr50 に着目すると, 周辺地盤である De で実験では $400 \mathrm{~mm}$, 解析では $300 \mathrm{~mm}$ となる大きな沈下が発生した。もちろん, 周辺地盤は完全 な自由地盤ではなく格子壁とせん断土槽の壁の影響を受けていると 考えられるが，解析でも実験の沈下量程ではないが大きな沈下を表 現することができている。Da から Dd 一格子間隔が広くなるほど沈 下量が大きくなるが，格子内地盤で最も沈下量が大きい格子間隔 Dd の実験での沈下量は $140 \mathrm{~mm}$ 程度で, 周辺地盤の沈下量の $35 \%$ ほどしか発生していない。また, 最も沈下量が小さい格子間隔 Da の実験での沈下量は $50 \mathrm{~mm}$ 程度で, 周辺地盤の沈下量の $13 \%$ にす ぎない。解析も概水実験の沈下量を再現できているといえる。次に Dr80 では Dr50 に比べ沈下量がかなり小さくなっている。Dr50の 時と同様に格子間隔が広くなるほど沈下量が増えるが，それでも格 子間隔が一番広い Dd の実験での沈下量は $50 \mathrm{~mm}$ 程度で周辺地盤の $220 \mathrm{~mm}$ の $22 \%$ 程の沈下量にとどまっている。また，数值解析にお いても周辺地盤は実験と差がみられるが格子内の沈下量は再現でき ているといえる。
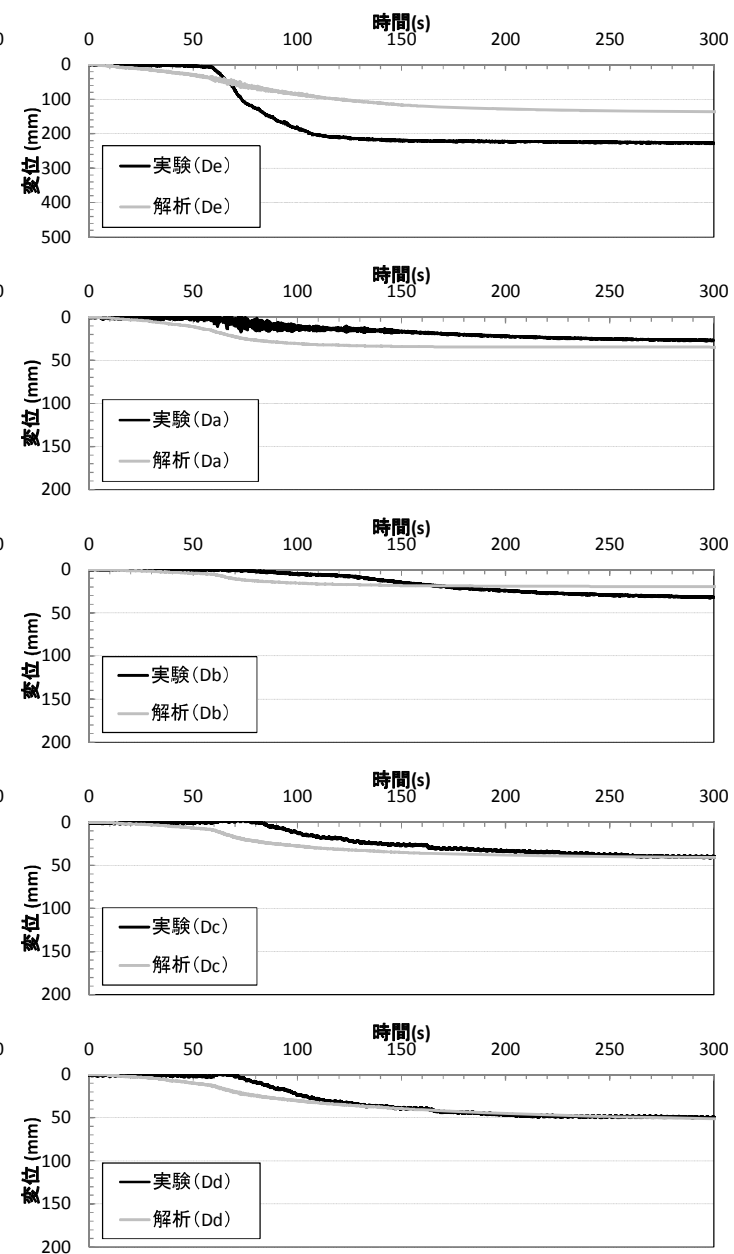

Dr80

図 7 沈下量の時刻歴 (実験結果, 解析結果) 

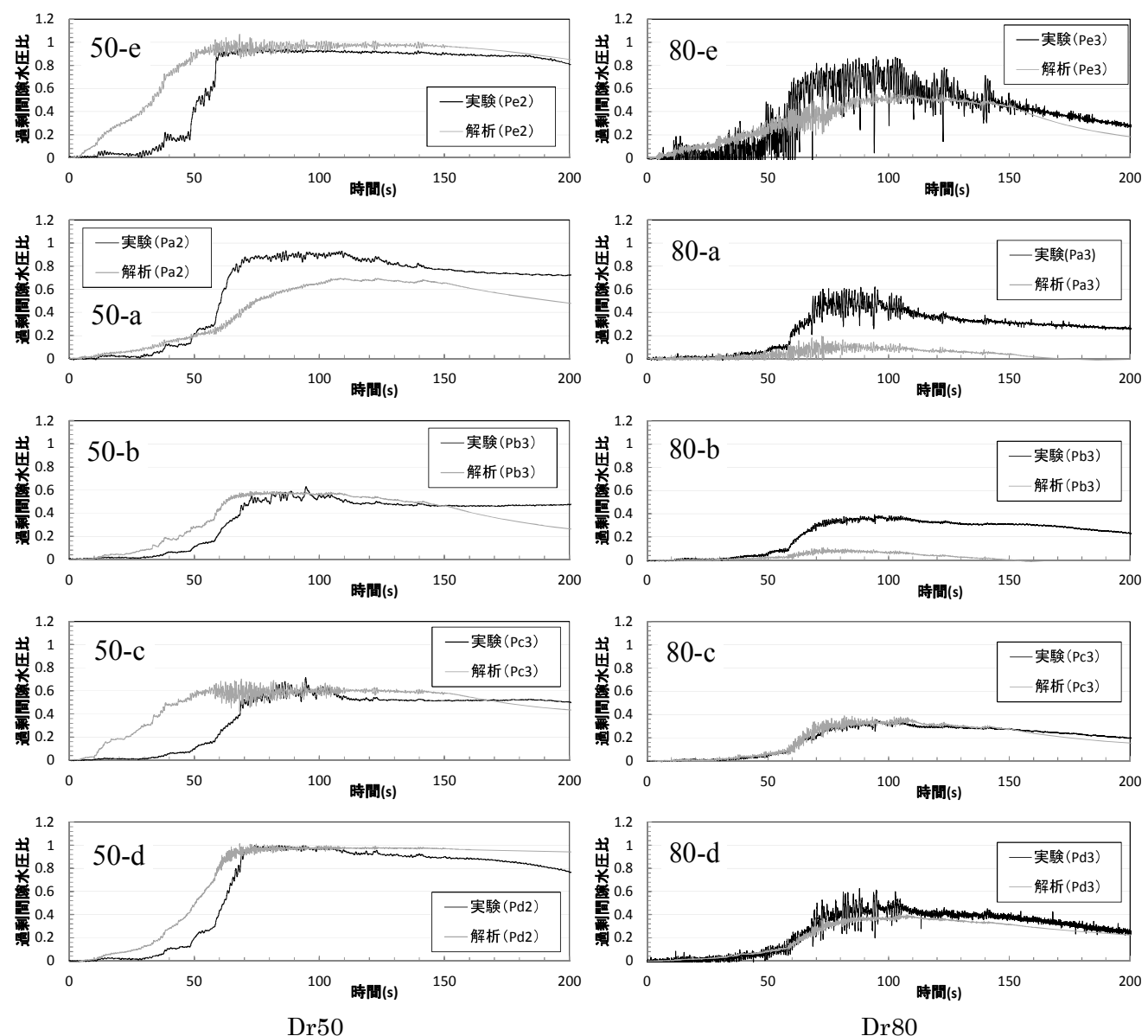

Dr50

Dr80

図 8 過剩間隙水圧比の時刻歴（実験結果，解析結果）

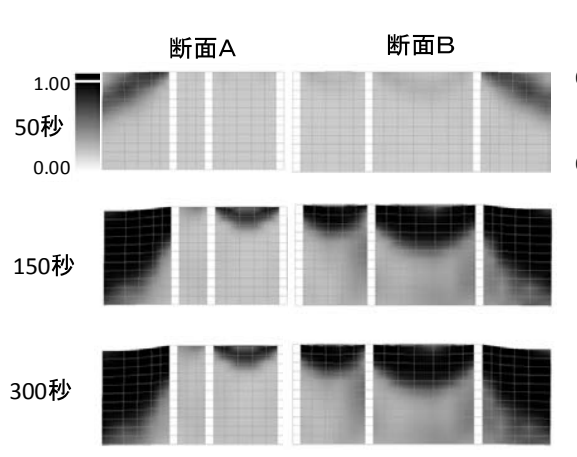

$R^{\star} \quad($ 構造の程度 $)$

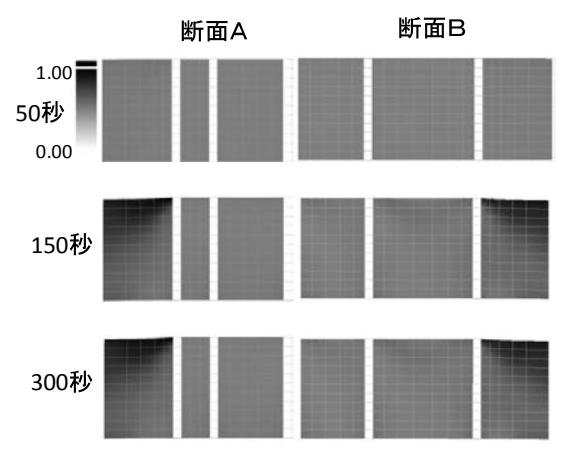

$R^{*} \quad($ 構造の程度 $)$

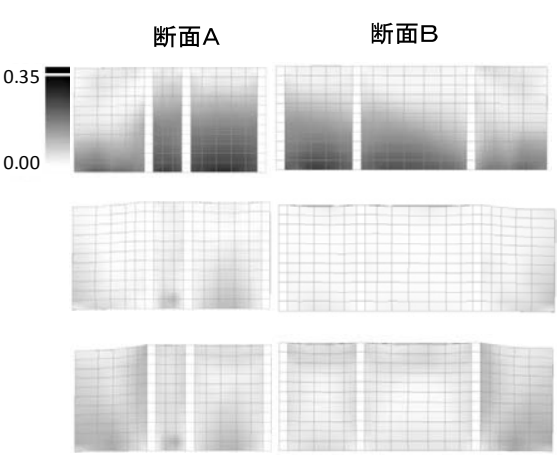

$R$ (過圧密比の逆数)

(a) Dr50
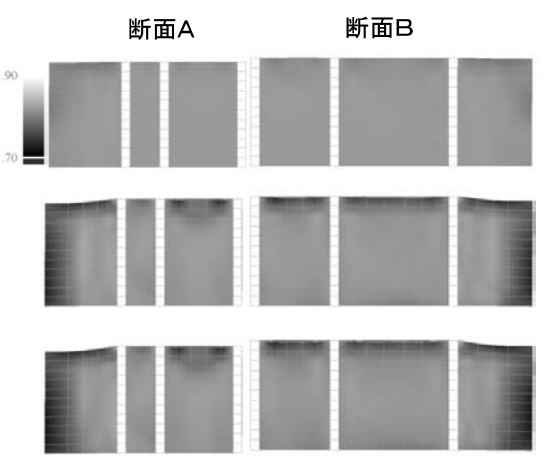

$v(=1+e)$ 比体積

断面B
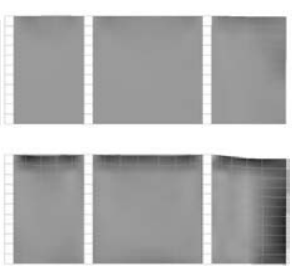
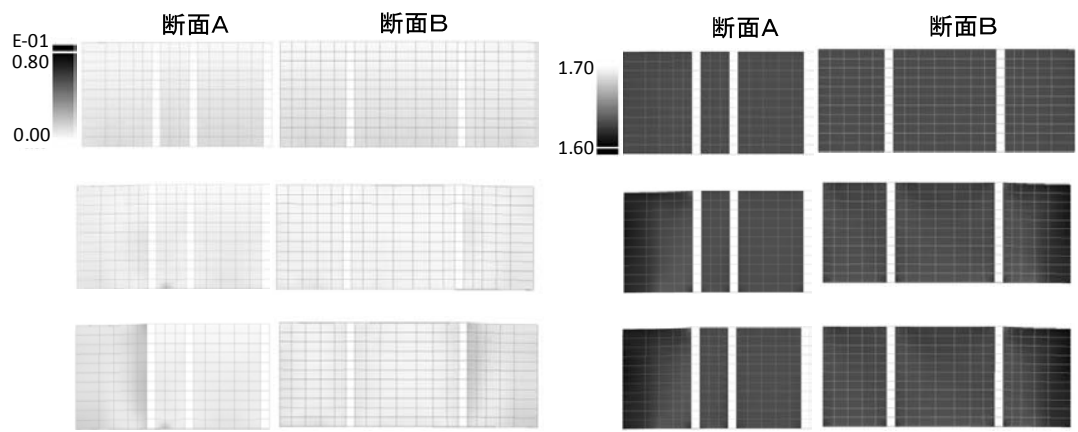

$R$ (過圧密比の逆数)

(b) $\operatorname{Dr} 80$

$v(=1+e)$ 比体積

図 9 構造 $R^{*}$,過圧密 $R$ および比体積 $(v=1+\mathrm{e})$ の計算結果の分布図 


\section{（2）過剰間隙水圧の比較}

図 8 に GL-2m の過剰間隙水圧比の実験結果と解析結果を示す(図 中の記号は図 1 を参照)。なお Dr50 に関して実験時の計測器の不良

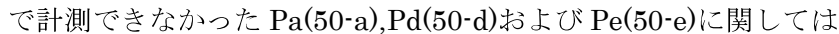
GL-6m の結果で数值解析の比較をする。相対密度 $50 \%$ の周辺地盤 の地表面近くの過剰間隙水圧比(50-e)が 1 となりそれに伴って図 7 では沈下が発生しているが，一番狭い間隔(50-a)では過剩間隙水圧 比が 1 未満となり液状化していないことが分かる。 $80 \%$ の地盤の周 辺地盤(80-e) は過剰間隙水圧比が 1 に近づくが沈下量としては小さ かった。格子間隔が一番狭い Pa については Dr50,80(50-a,80-a)と も，Pbについては $\operatorname{Dr} 80(80-b)$ で実験に比べ解析は過劋間陌水圧が 小さい結果となった。これは実験時の地盤の作製や格子の剛性の影 響があると考えている。全体的に初期の立ち上がりに実験と解析に 違いがみられるものの概ね解析は実験を再現できている。なお，過 剩間隙水圧の立ち上がりや沈下の発生時間に解析と実験で違いがみ られるが，これは構造の劣化パラメータや透水係数などを含めて今 後の課題としたい。

\section{（3）地盤内の挙動}

次に沈下と構造の程度, 過圧密の関係について調べる。図 9 に図 4 に示す $\mathrm{A}$ および $\mathrm{B}$ 断面で整理した地盤の側面における $R^{*}, R$ およ び比体積 $(v=1+\mathrm{e})$ の計算結果の分布図を示す。Dr50 では 50 秒（加 振中）では構造の程度 $R^{*}$ は周辺地盤で 1 に近づいているが格子内 ではまだ初期の 0.2 のままである。150 秒（加振終了時）では $R^{*}$ は周辺地盤ではほとんど 1 に近づき格子間隔が広くなるほど地表面 で構造劣化 $\left(R^{* \rightarrow 1}\right)$ が進んでいる。過圧密比の逆数である $R$ は加振

周辺地盤

(De)

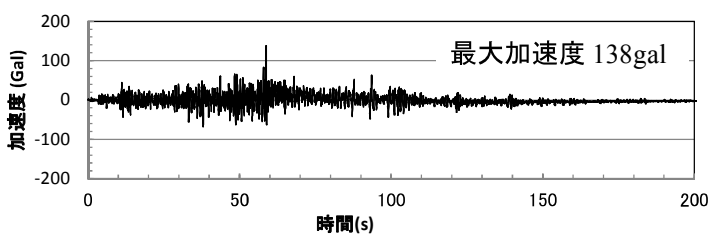

Da

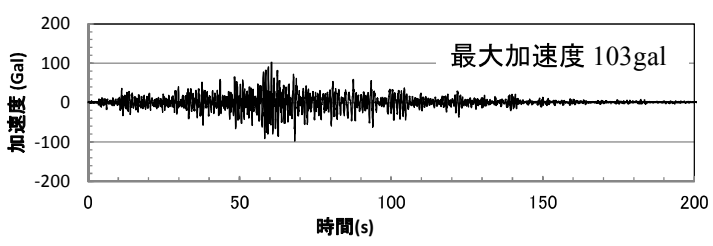

実験結果(Dr50)

周辺地盤

(De)

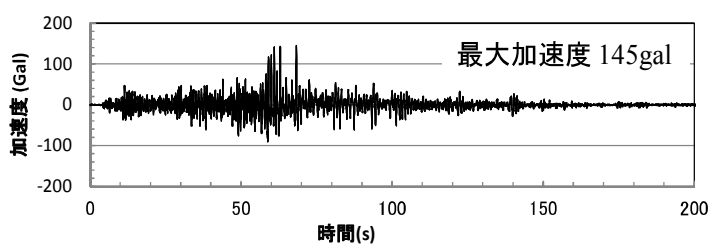

$\mathrm{Da}$

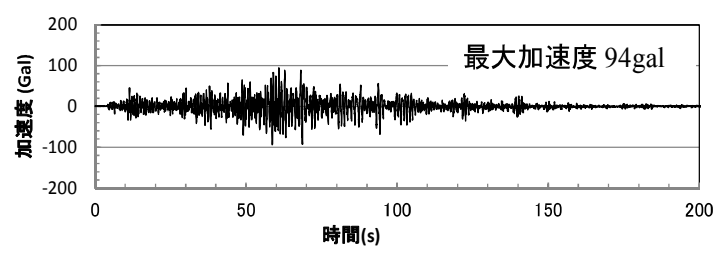

実験結果(Dr80)
が進み構造劣化が進むと同時に值が小さくなる。これは図 10 に概 念図を示すように有効応力が増加せずに構造の劣化が進むと間隙が 圧縮するため過圧密比が大きくなっていくことが示されている。ま た比体積の分布をみると構造劣化が進むところで比体積が小さくな り土骨格が圧縮していることが分かる。これは図 7 の沈下量の時刻 歴を見ると 50 秒までは沈下量が少ないがその後沈下量が増えてい くことに対応する。また， 300 秒後ではわずかに構造劣化が進む。 Dr80 の場合は初期地盤として構造の程度 $R^{*}$ が Dr50 に比べ大きく また過圧密の逆数である $R$ が小さいため加振とともに周辺地盤は構 造の劣化が進み圧縮が進むが Dr50 ほど顕著ではなく沈下量が小さ いことが分かる。密度の違う砂地盤で発生する沈下量の違いはこの ように構造の劣化や, 過圧密の程度によって統一的に表現すること ができる。今回の解析のように液状化地盤では液状化中あるいは液 状化後に地盤が圧縮・沈下寸るが，乾燥砂や排水条件で見られる地 盤の締固めも同様なメカニズムで説明できる ${ }^{8)}$

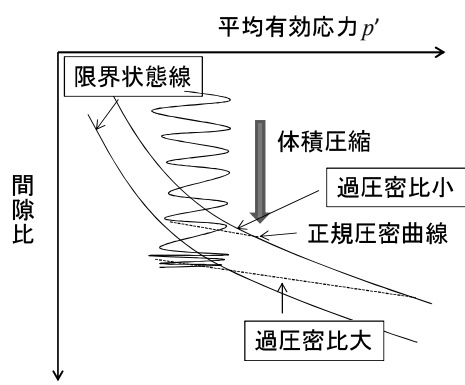

図 10 土の圧縮の概念図
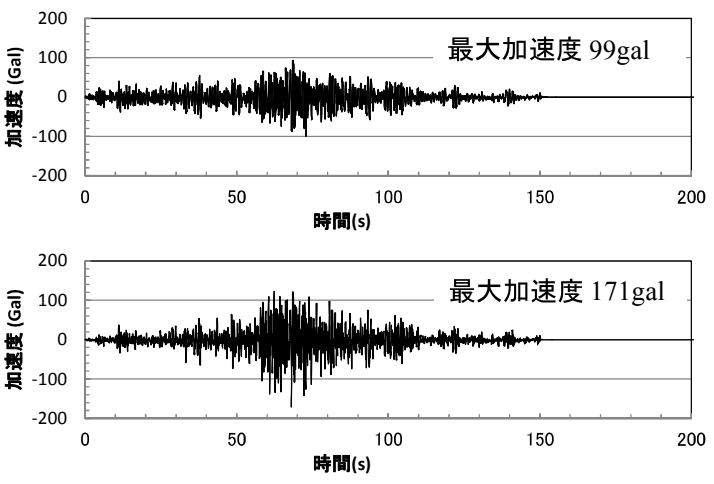

解析結果 (Dr50)
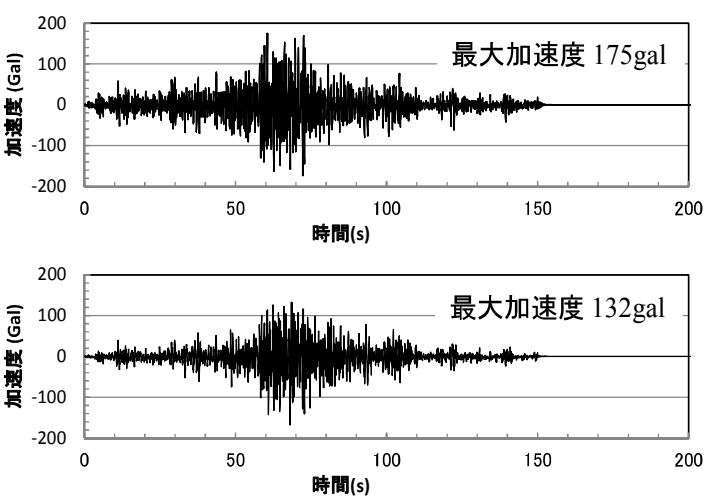

解析結果 (Dr80)

図 11 応答加速度の時刻歴（実験結果，解析結果） 


\section{（4）水平加速度の比較}

図 11 に GL-2m での周辺地盤 De と格子間隔が一番小さい Da の 加速度時刻歴について実験と解析結果を示す。Dr50 の周辺地盤に ついて実験は主要動が始まる 60 秒付近で最大加速度となり, その 後は図 2 の入力地震動と比べて応答が落ちていることから液状化が 発生していると考えられる。数值解析も実験結果ほどではないが全 体的に加速度応答が小さくなっており液状化している。Daについ ては最大加速度は小さいが全体的に周辺地盤より大きくなり，実験 結果より解析結果はさらに大きくなった。Dr80については Dr50 に比心液状化による応答の低下は小さく, 解析結果は実験結果より 応答が若干大きくなる傾向にあった。加速度応答については地盤と 格子とのすべりなどの境界条件を含めさらに検討する必要があると 考えている。

\section{4. まとめ}

格子状地盤改良の地震時の沈下や過剩間隙水圧について遠心模型 実験を実施し, 数值解析で再現を行った。

遠心模型実験では格子面積が小さくなると地表面沈下量も小さく なり，一番広い間隔のケースでは相対密度 $50 \%$ の地盤に関しては周 辺地盤に比べ $35 \%, 80 \%$ の地盤は $22 \%$ ぼの沈下が低減されること が示された。相対密度 $50 \%$ の周辺地盤の地表面近くの過㮃間隙水圧 比が 1 となり沈下が発生しているが，一番狭い間隔では過剩間隙水 圧比が 1 未満となり液状化していないことが示された。相対密度 80\%の地盤でも 1 に近づくが沈下量としては小さかった。

地盤の構成式として SYS カムクレイモデルを導入し, 地震時の沈 下評価を行った。このモデルは土の骨格構造（構造, 過圧密, 異方 性)の働きを記述する弾塑性構成式で相対密度は構造の程度 $R^{\star} に よ$ って評価できる。数值解析結果は沈下量, 過剩間隙水圧比および加 速度応答に関しておおむね実験結果を再現することができた。土骨 格の圧縮は構造の劣化と過圧密の蓄積によって表現できることを示 した。

極大地震などの耐震評価として地盤の変形を評価する手法が必要 になると考えられる。今後はさらに実験との比較を行い, 本手法の 適用性の検討を進めるとともに改良壁厚の影響などについて検討を していく予定である。

\section{参考文献}

1）地盤工学会編：地震時における地盤災害の課題と対策－2011 年東日本大 震災の教訓と提言一(第一次), 2011

2）内田明彦，小田島暢之，山下清: 東北地方太平洋沖地震における格子状地 盤改良を施した建物基礎の挙動，日本建築学会技術報告集，Vol.19, No.42， pp.481-484, 2013.

3）鈴木吉夫, 斎藤聡, 鬼丸貞友, 木村玄, 内田明彦, 奥村良介 : 深層混合処 理工法を用いた格子状地盤改良による液状化対策工,土と基礎, Vol.44, No.3, pp.46-48, 1996

4）古賀泰之, 松尾修, 榎田実, 伊藤浩二, 鈴木吉夫 : 深層混合処理工法によ る砂地盤の液状化対策に関する模型振動実験(その 2) - 格子状改良地盤の 液状化抑制効果について - , 土質工学研究発表会, pp.1019-1020, 1998

5）高橋英紀，山脇秀仁，北詰昌樹，石橋信司：深層混合処理による液状化抑 制効果の検討及び改良深度縮減した新しい格子配置の提案, 港湾空港技術研 究所報告, 第 45 巻, 第 2 号, 2006 .

6）入江潤，鈴木吉夫，馬場崎亮一：深層混合処理工法を用いた格子状改良地 盤による液状化対策一遠心模型振動実験による液状化抑止効果の検証その 1 一, 日本建築学会大会学術講演梗概集，構造 I , pp.783-784, 1997.
7) Asaoka, A., Noda, T., Yamada, E., Kaneda, K. and Nakano, M.: An elasto-plastic description of two distinct volume change mechanisms of soils, Soils and Foundations, Vol.42, No.5, pp. 47-57, 2002.

8）金田一広, 内田明彦, 津國正一：格子状地盤改良の格子間隔の違いによ る沈下評価，日本建築学会大会学術講演梗概集，構造 I , pp667-668, 2014

9）津國正一, 小西一生, 内田明彦: 格子状地盤改良内で発生する沈下量に 着目した遠心模型振動実験，土木学会論文集部門 C（地圏工学）,Vol.70, No.3, pp301-312, 2014

10) Asaoka, A. : Consolidation of clay and compaction of sand -An elasto-plastic description-, Keynote lecture, Proc. of 12th Asian Regional Conf. on Soil Mechanics and Geotechnical Engineering, Leung et al. Singapore, Aug., Vol,2, pp.1157-1195, 2003. 


\title{
SIMULATIONS OF SETTLEMENT ABOUT THE GRID SPAN OF \\ GRID-FORM DEEP MIXING WALLS UNDER EARTHQUAKE
}

\section{Kazuhiro KANEDA*, Shoichi TSUKUNI**, Tsuyoshi HONDA* and Akihiko UCHIDA*}

\author{
${ }^{*}$ Chief Researcher, Takenaka Research \& Development Institute, Dr. Eng. \\ ** Senior Manager, Technology \& Production Development Division, Takenaka Civil Engineering \& Construction Co., Ltd., M. Eng.
}

For liquefaction countermeasure based on grid-form deep mixing walls, the grid interval has conventionally been designed using the excess pore water pressure ratio or the FL value, and conditions under which liquefaction does not occur in the ground within the grid. However, in the case of seismic motions with a long duration, such as that which occurred during the 2011 earthquake off the Pacific coast of Tohoku, used as a design seismic motion, the increase in the excess pore water pressure in the ground within the grid becomes greater than that for a seismic motion with a shorter duration and an equivalent acceleration level. Centrifuge model vibration testing and numerical simulations were conducted to obtain the knowledge required for a performance design focused on settlement occurring in the ground within the grid. The sands with different relative densities are usually in a structured, overconsolidated and anisotropic state. The Super/subloading Yield Surface Cam-clay model with rotational hardening (SYS Cam-clay model) is powerful for incorporating these features. We found that the numerical simulations reproduced the experimental data well. It is indicated that there is the possibility of settlement evaluations under earthquake. 